\title{
NOTE
}

\section{Enrichment of trace elements in ferromanganese concretions from terra rossa and their potential desorption}

\author{
Jin-Liang Feng, ${ }^{1 *}$ Yong-Chong Lin, ${ }^{1,2}$ ShaO-Peng GAO ${ }^{1,3}$ and Ji-Feng ZHANG ${ }^{1,2}$ \\ ${ }^{1}$ Key Laboratory of Tibetan Environment Changes and Land Surface Processes, Institute of Tibetan Plateau Research, \\ Chinese Academy of Sciences, Beijing 100101, China \\ ${ }^{2}$ Graduate University of the Chinese Academy of Sciences, Beijing 100049, China \\ ${ }^{3}$ School of Energy Resources, China University of Geosciences, Beijing 100083, China
}

(Received July 12, 2011; Accepted December 12, 2011)

\begin{abstract}
The distributions of trace elements in ferromanganese concretions (FMCs) and the surrounding terra rossa (TR) matrix overlying dolomite have been examined to extend our understanding of their mobilization, redistribution and fractionation during karst weathering and pedogenesis. This study demonstrates that the characteristics of trace elements in TR have been severely overprinted by weathering and pedogenetic processes. The composition of trace elements in FMCs within TR soil profiles varies greatly with depth. The concentrations of $\mathrm{Be}, \mathrm{Ni}, \mathrm{Cu}, \mathrm{Zn}, \mathrm{As}$ and $\mathrm{Bi}$ in FMCs fluctuate and tend to increase with depth; other trace element concentrations fluctuate in the profile but show no clear trend. The toxic elements $\mathrm{Cr}, \mathrm{As}, \mathrm{Cd}, \mathrm{Tl}$ and $\mathrm{Pb}$, as well as $\mathrm{Co}$, are significantly enriched in FMCs relative to the surrounding TR matrix: arsenic exhibits strong affinity with $\mathrm{Fe}$, but $\mathrm{Cr}$ and $\mathrm{Cd}$ contents are not significantly correlated with either Mn or $\mathrm{Fe}$. Correspondingly, $\mathrm{Co}, \mathrm{Tl}$ and $\mathrm{Pb}$ are related to the $\mathrm{Mn}$ in FMCs rather than the Fe. In FMCs, trace element distribution and partitioning in the $\mathrm{Mn}-\mathrm{Fe}$ phases are governed by the location-specific formational pedoenvironment, with the weathering front etching downwards. Experiments with simulated acid rain indicate that desorption of elements from FMCs is generally $\mathrm{pH}$-dependent regardless of the variation of the released amounts and their desorbability. Moreover, it seems that toxic elements bonded to Mn-phase were easily desorbed from FMCs. As a result, the bioavailability, mobility and activity of some toxic elements in FMCs and TR are potentially increased in field areas experiencing severe soil erosion and acid rain.
\end{abstract}

Keywords: dolomite, karst weathering, terra rossa, ferromanganese concretions, simulated acid rain, toxic element desorption

\section{INTRODUCTION}

Ferromanganese concretions (FMCs) occur mainly in soils and in lacustrine and pelagic sediments (McKenzie, 1975; Williams and Owen, 1992; Verlaan et al., 2004; Feng, 2010, 2011). Marine FMCs have been extensively studied because of their economic potential (Calvert and Piper, 1984; Ahmad and Husain, 1987; Glasby et al., 1987). In spite of having little economic potential, FMCs in soils possibly play an important role for the pedobiosphere. $\mathrm{Mn}$ and $\mathrm{Fe}$ are important elements for plant and animal nutrition (Liu et al., 2002). In addition, oxides and/or hydroxides of both $\mathrm{Mn}$ and $\mathrm{Fe}$ are the main $\mathrm{Mn}-\mathrm{Fe}$ phases in the soils, and they often act as strong scavengers of trace elements during weathering and pedogenesis (Burns, 1976; McKenzie, 1980; Bellanca et

\footnotetext{
*Corresponding author (e-mail: fengjl@itpcas.ac.cn)

Copyright $@ 2012$ by The Geochemical Society of Japan.
}

al., 1996; Palumbo et al., 2001; Cornu et al., 2005; Feng, 2011). Therefore, knowledge of the distribution of trace elements in FMCs is valuable in geochemical exploration since it provides a valid procedure for selection of sample medium and extraction, and helps evaluate the significance of analytical data (Chao and Theobald, 1976; Miko et al., 1999). On the other hand, $\mathrm{Mn}$ and $\mathrm{Fe}$ also affect the mobility of trace elements in soils and the phytoavailability of both nutrient and toxic trace elements (Bellanca et al., 1996; Palumbo et al., 2000, 2001; Liu et al., 2002). Through mechanisms such as co-precipitation, adsorption and lattice substitution, among others, the trace elements are scavenged from the soil solution, and are incorporated into FMCs (Chao and Theobald, 1976); however, once the pedoenvironment has been changed, the trace elements adsorbed in FMCs become chemically unstable, possibly desorbing into the soil solution (Taylor and McKenzie, 1966; Bellanca et al., 1996).

Although trace elements in FMCs from many soils have been studied (Taylor and McKenzie, 1966; Dawson 


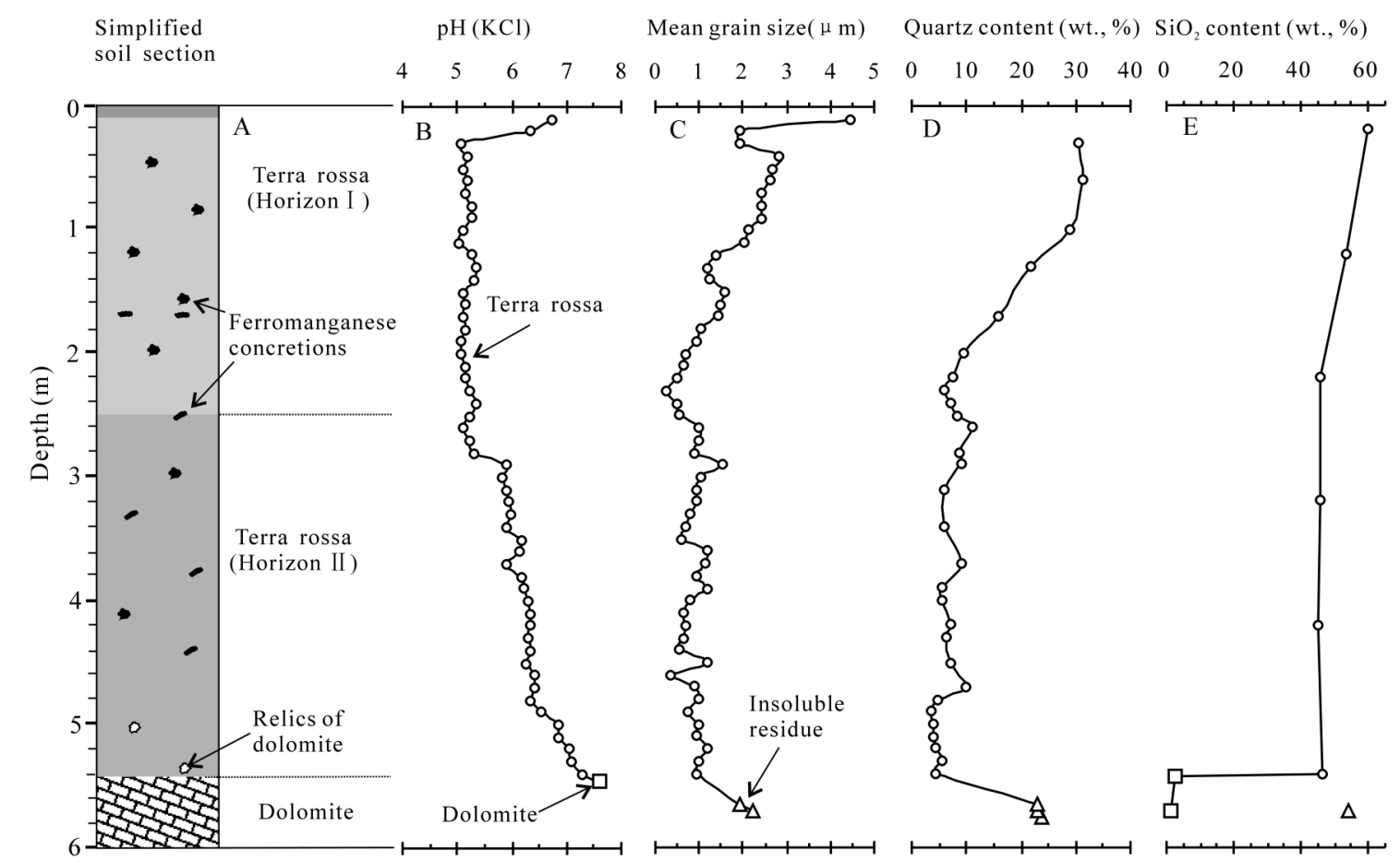

Fig. 1. (A) Simplified stratigraphic section of TR profile at the Dashandong site; (B) variation of pH (KCl) value in TR matrix with depth; $(C)$ variation of mean grain size in TR matrix with depth; $(D)$ variation of quartz content in TR matrix with depth; $(E)$ variation of $\mathrm{SiO}_{2}$ content in TR matrix with depth (after Feng et al., 2009a).

et al., 1985; Latrille et al., 2001; Liu et al., 2002; Cornu et al., 2005), few have focused on the distribution of trace elements in FMCs at different depths in the soil profile (Feng, 2010, 2011). There is also a lack of information both on the direct quantitative relationship between $\mathrm{Mn}-$ Fe phases and trace elements, and on the comparative capacities of the $\mathrm{Mn}$ - and $\mathrm{Fe}$-phases to retain trace elements in FMCs at different depths and in various pedoenvironments (Chao and Theobald, 1976).

The origin of terra rossa (TR) and its relationship with the underlying carbonate rocks poses long-standing and controversial questions (Yaalon, 1997; Durn et al., 1999; Wang et al., 1999; Durn, 2003; Ji et al., 2004; Singer, 2007; Merino and Banerjee, 2008; Feng et al., 2009a, b; Muhs and Budahn, 2009; Muhs et al., 2010). Some TR is not the product of weathering in situ, and therefore does not have a close genetic relationship with the carbonate rocks underlying it, and probably does not provide the best opportunity for uncovering the behavior of trace elements during karst weathering (Feng et al., 2009a, b); however, trace elements have been used to determine TR origin (Whitehead et al., 1993; Ji et al., 2004; Mee et al., 2004; Muhs and Budahn, 2009; Muhs et al., 2010). Whatever the case may be, a sound knowledge of the geochemical behavior of trace elements during karst weathering and pedogenesis is required for logically trac- ing the TR origin (Feng, 2011).

The present study investigated a $5.4 \mathrm{~m}$ thick in situ terra rossa weathering profile overlying dolomite. FMCs occur in the TR (Feng et al., 2009a). The main objectives of the study were to investigate (1) the trace element composition in the FMCs and TR matrix, and their distribution in the profile; (2) the enrichment behavior of trace elements in the FMCs compared to the surrounding TR matrix; (3) specific inter-element associations between $\mathrm{Mn}$ and $\mathrm{Fe}$ and the trace elements in the FMCs; and (4) the potential desorption of trace elements from the FMCs and TR due to human activity.

\section{Geological Setting and Data on the TR Profile}

The Dashandong terra rossa profile lies $4 \mathrm{~km}$ northwest of Guiyang city, on the Yunnan-Guizhou Plateau in south-western China. The sampling site lies at the pediment of a karst hill with TR up to $5.4 \mathrm{~m}$ thick overlying Early Triassic dolomite (Feng et al., 2009a).

Field observations showed that the TR profile is heterogeneous in both color and texture, and comprises two horizons (Fig. 1). Horizon I $(0-2.5 \mathrm{~m})$ is silty clay and clay: light-brownish-grey soil and anthropogenic slag deposits $(0-0.1 \mathrm{~m})$, silty clay, mainly reddish-yellow $(0.1-$ $1.2 \mathrm{~m})$, and reddish-yellow clay $(1.2-2.5 \mathrm{~m})$ that exhibits 
enhanced plasticity and has a massive and compact structure. A few FMCs (generally $1-4 \mathrm{~mm}$ in diameter) are scattered below $0.4 \mathrm{~m}$, with brown pisolitic or crustose surfaces (sample DSD-39FMC, dry powder, Munsell color 7.5YR 4/4; others colored 10YR 4/3). Enrichment of some crustose FMCs occurs at approximately $1.7 \mathrm{~m}$ depth, with a maximum concretion size of $3 \times 2.5 \times 1 \mathrm{~cm}$ (sample DSD-38FMC). The largest pisolitic concretion, $8 \mathrm{~mm}$ in diameter, was found at $2.0 \mathrm{~m}$ depth (sample DSD35FMC); its internal structure displayed a discontinuous succession of concentric bandings based on backscattered electron (BSE) imaging observations (Feng et $a l ., 2003)$. Its boundary with the underlying horizon was gradual and irregular.

Horizon II (2.5-5.4 m) consists of mottled clay with common reddish-yellow to light-grey spots. The TR exhibits a clayey texture, a massive and blocky structure, and a complete lack of visible bedding features or clear transitions. A few flake-like, reddish-brown FMCs (dry powder, Munsell color 2.5YR 4/4 for samples DSD30FMC, DSD-22FMC, DSD-17FMC and DSD-11FMC) and fine pisolitic FMCs (generally $<1 \mathrm{~mm}$ in diameter), brown in color (dry powder, Munsell color 10YR 4/3 for sample DSD-14FMC) were found at depths of 2.5 to 4.4 $\mathrm{m}$. Additionally, a few strongly weathered dolomite relics were included in the TR matrix between 5.0 and 5.4 $\mathrm{m}$ depth (Fig. 1A). The contact between the TR and the underlying dolomite was sharp and irregular.

The dolomite bedrock occurs at a depth of $5.4 \mathrm{~m}$, being strongly weathered from 5.4 to $5.45 \mathrm{~m}$. The weathered dolomite crumbles easily to dolomitic sand. Below $5.45 \mathrm{~m}$, weakly weathered dolomite gradually transits into hard dolomite.

Disturbed bulk samples of TR collected at $0.1 \mathrm{~m}$ intervals in the fresh profile were used for FMC collection and for major and trace element analyses. FMCs were handpicked from the bulk TR samples and cleaned ultrasonically in super-pure water.

The fresh dolomite contained $0.69 \%$ insoluble residue (IR) on average following acid treatment, consisting of illite, illite/smectite mixed-layer minerals, quartz, hematite, pyrite, and small amounts of feldspar (Feng et al., 2009a).

$\mathrm{X}$-ray diffraction (XRD) powder analysis showed that the brown FMCs contained gibbsite, quartz and small amounts of illite and kaolinite (Feng et al., 2011), suggesting goethite as the principal crystalline component of the Fe phase. By contrast, the sheet-like, reddish-brown FMCs comprised quartz, hematite, illite and kaolinite; analysis suggested that hematite was the principal crystalline component of the Fe phase in these concretions. However, XRD analysis of the FMC samples did not reveal distinct peaks for Mn-oxide minerals, probably due to the poorly crystallized Mn mineral phase.
Feng et al. (2009a) suggested that the TR in the Dashandong profile is probably an in situ weathering crust, based on content, grain size distribution, morphology and $\delta^{18} \mathrm{O}$ of the contained quartz; however, the parent rocks are vertically heterogeneous. The TR partly consists of the insoluble residue of the underlying dolomite, enriched by elements imported by percolating external soil-water and/or from pre-existing TR at the top of the profile.

\section{METHODS}

Insoluble residue (IR) in the dolomite was isolated by: (1) treating with $0.3 \mathrm{M}$ acetic acid (HOAc) at room temperature, retaining some undissolved dolomite at all times to help prevent alteration of the characteristics of the clays (Ostrom, 1961); then (2) dissolving the residual dolomite using a pH 4.5 HOAc/NaOAc buffer (Rabenhorst and Wilding, 1984).

Powder samples of the TR matrix (excluding possible FMCs), FMCs, dolomite, and IR from the underlying dolomite were dissolved using the pressurized aciddigestion procedures described by Qi et al. (2000). The concentration of trace elements in all samples, and the $\mathrm{Mn}$ and Fe content in the TR matrix (excluding possible FMCs), the dolomite and the IR from the underlying dolomite were all measured on an inductively coupled plasma mass spectrometer (ICP-MS; X-7 series) at the Institute of Tibetan Plateau Research (ITP), Chinese Academy of Sciences (CAS). For quality control, the USGS reference material AGV-2 (andesite) was analyzed. The difference between our laboratory data and the recommended and information values for AGV-2 was $<5 \%$ for $\mathrm{Li}, \mathrm{Sc}, \mathrm{Ti}, \mathrm{V}$, $\mathrm{Cr}, \mathrm{Mn}, \mathrm{Fe}, \mathrm{Co}, \mathrm{Ni}, \mathrm{Cu}, \mathrm{Rb}, \mathrm{Sr}, \mathrm{Zr}, \mathrm{Ba}, \mathrm{Ta}, \mathrm{Tl}, \mathrm{Pb}$, Th and $\mathrm{U}$, and $<10 \%$ for $\mathrm{Be}, \mathrm{Zn}, \mathrm{Ga}, \mathrm{Nb}, \mathrm{Cs}$ and $\mathrm{Hf}$. (No recommended and information values are available for B, As, $\mathrm{Cd}, \mathrm{Sn}$ or $\mathrm{Bi}$ in conjunction with the reference material AGV-2. See Appendix Table A1 available at http:// www.terrapub.co.jp/journals/GJ/archives.html.) The Mn and Fe content in the FMCs was measured using the inductively coupled plasma optical emissions spectrometer (ICP-OES; Prodigy, Teledyne Leeman Labs) at ITP, CAS.

The effect of $\mathrm{pH}$ change on the processes of trace element desorption from FMCs was determined using the simulated acid rain method. Based on the chemical composition of the rainfall in southern China, the simulated acid rains in this experiment were $4: 1 \mathrm{H}_{2} \mathrm{SO}_{4}: \mathrm{HNO}_{3}$ mole ratio at $\mathrm{pH}$ values 2.1, 3.0, 4.0 and 5.4 (Wang et al., 2009). A solution of each of these was added to test tubes containing $0.5 \mathrm{~g}$ samples of FMCs (sample DSD-38FMC) at a sample:solution ratio of 1:20. The suspensions were shaken for $2 \mathrm{~h}$ in a horizontal reciprocating shaker (120 $\mathrm{rpm}, 26^{\circ} \mathrm{C}$ ). After further equilibration for $22 \mathrm{~h}$ at room temperature, the suspensions were centrifuged and the 

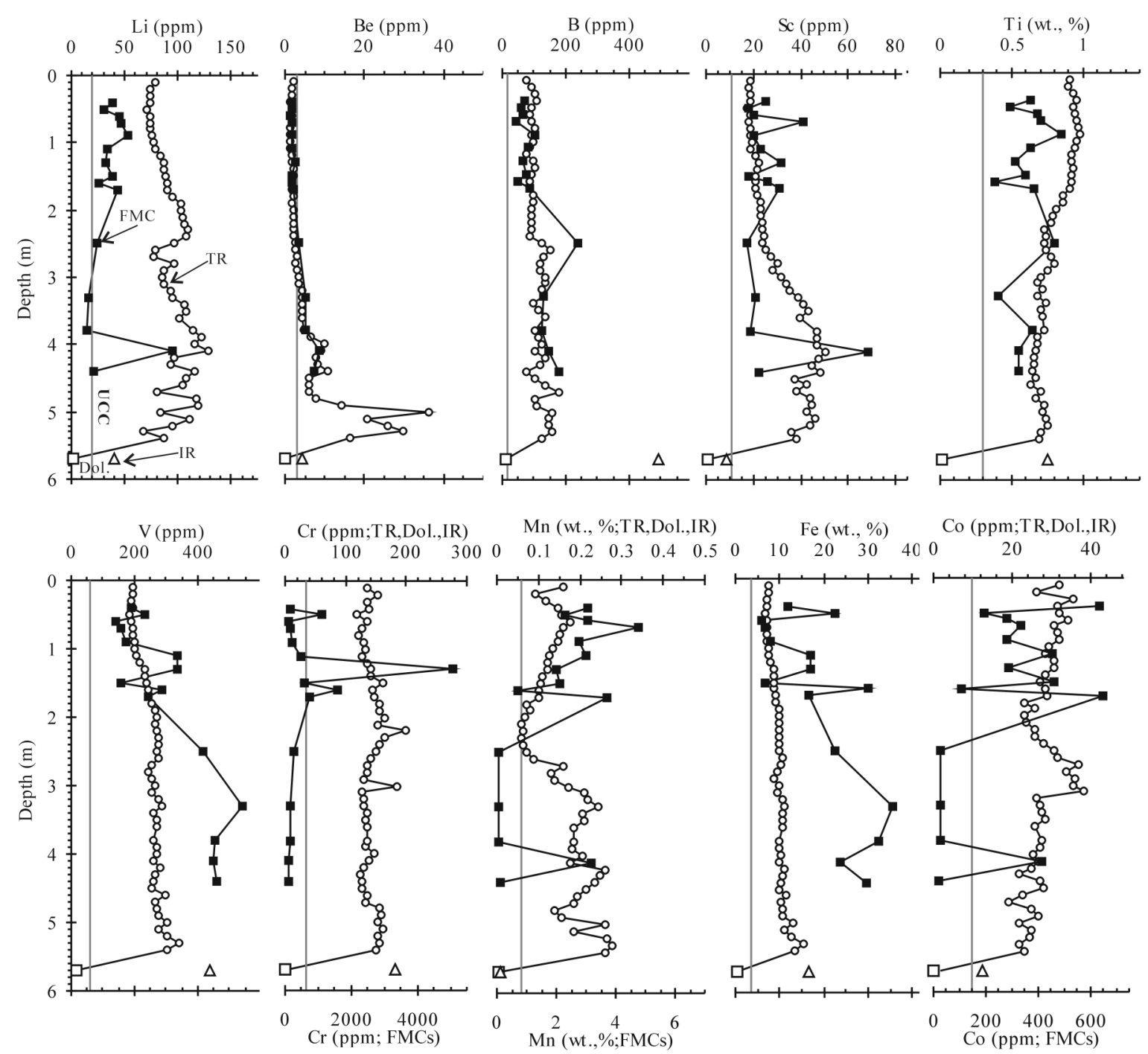

Co (ppm;TR,Dol.,IR)
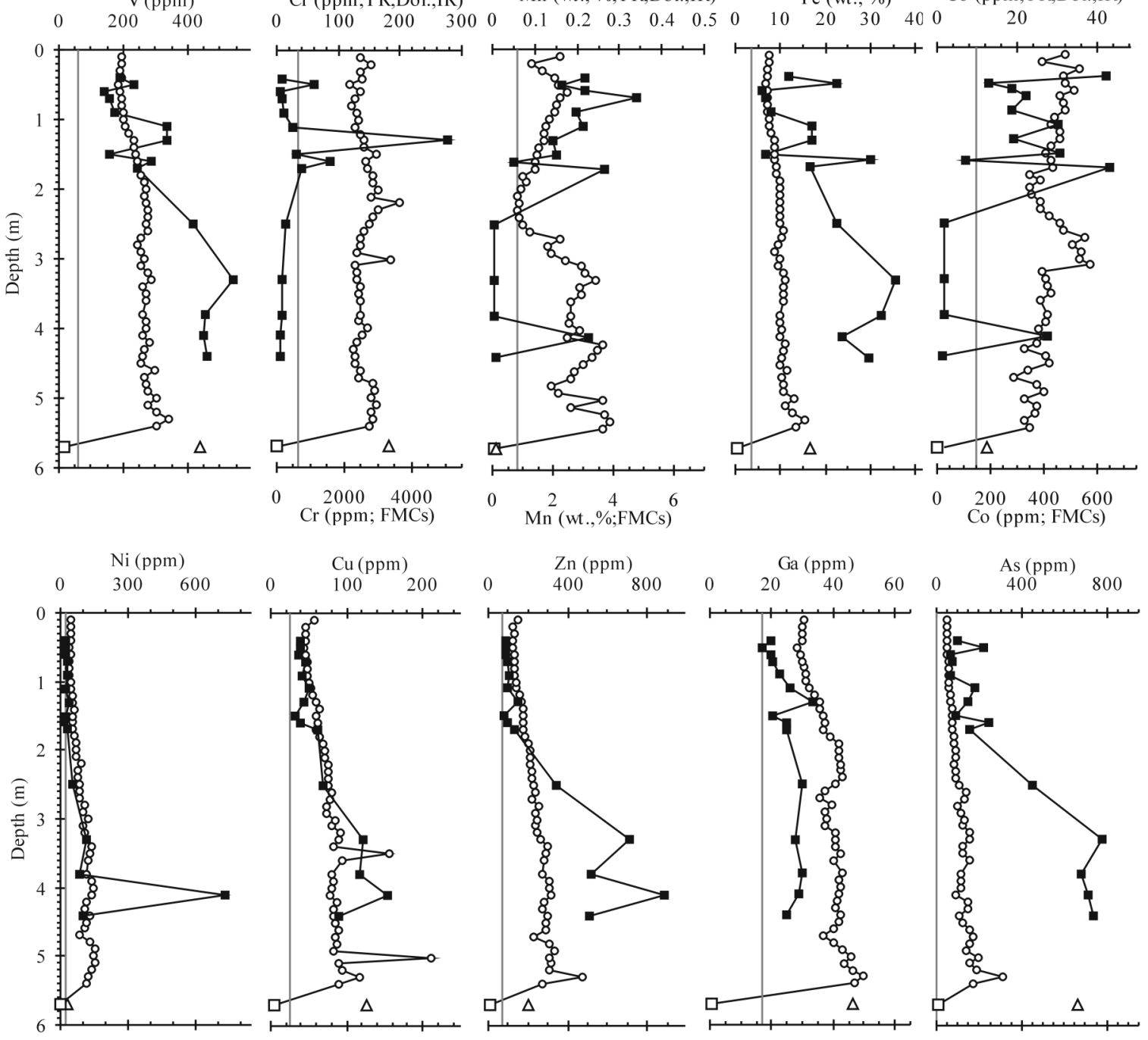

Fig. 2. Concentration of trace elements in FMCs, TR matrix, dolomite (Dol.) and IR from the underlying dolomite varies with depth in the Dashandong profile. Element concentration of the upper continental crust (UCC); data after Taylor and McLennan (1985) shown for comparison. 

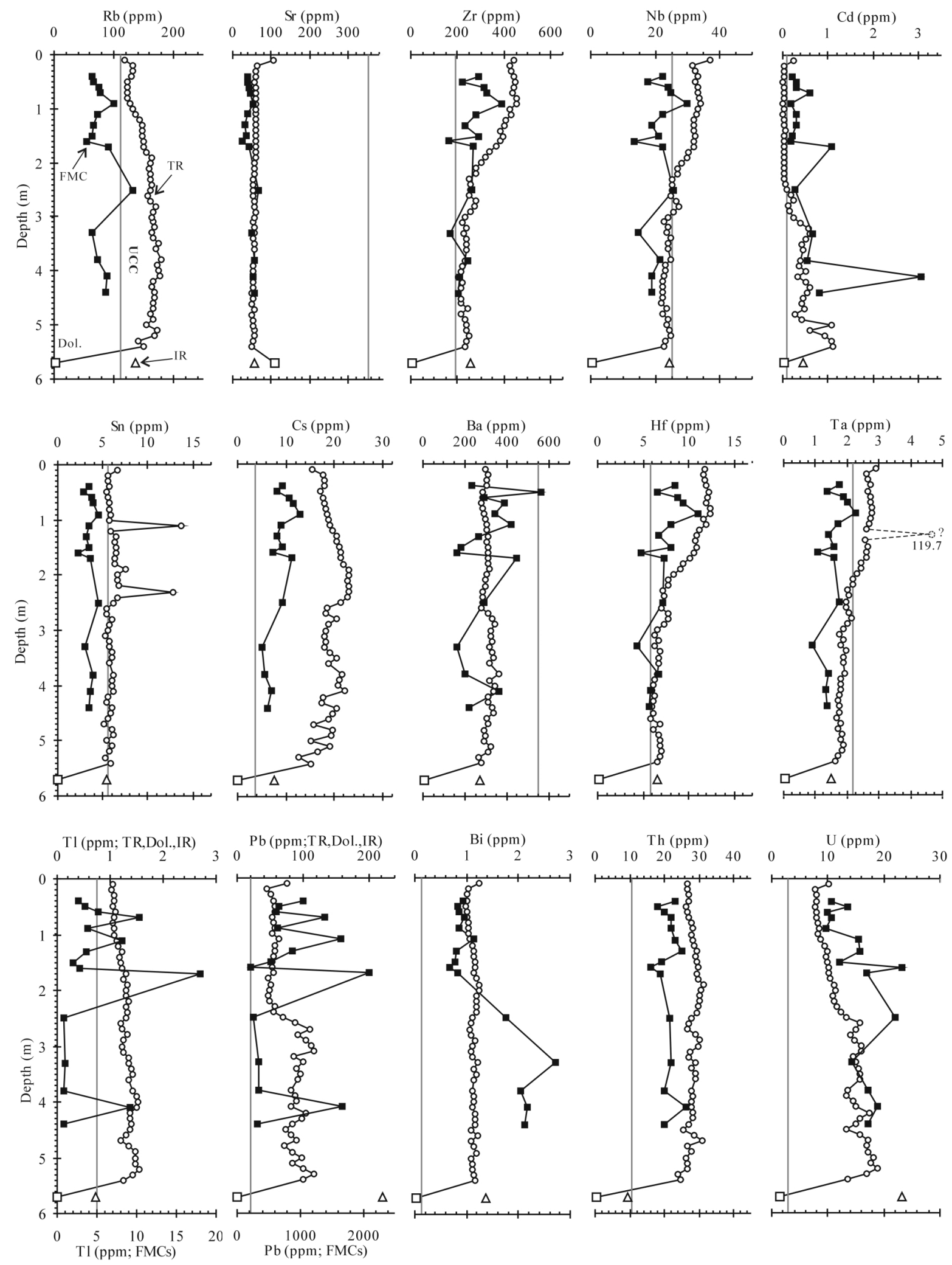

Fig. 2. (continued). 
residual FMCs then rinsed twice with Milli-Q ${ }^{\mathrm{TM}}$ water (resistivity $18.2 \mathrm{M} \Omega \cdot \mathrm{cm}$ ). The leachates were filtered on $0.45 \mu \mathrm{m}$ syringe filters in preparation for measuring the concentrations of released elements using the ICP-MS at ITP. Meanwhile, blank determinations with solutions at various $\mathrm{pH}$ had been completed. The released amounts of elements from the FMCs were calculated on the basis of untreated sample weight. The desorbability of the elements in the FMCs (amount desorbed expressed as a percentage of the total) was calculated from their concentrations in the bulk FMCs.

\section{RESULTS AND DISCUSSION}

Figure 2 shows the trace element concentration in the FMCs, the surrounding TR matrix, the dolomite and the IR from the underlying dolomite, at different depth (Appendix Table A2 including these data is available at http: //www.terrapub.co.jp/journals/GJ/archives.html). Although $\mathrm{Ti}, \mathrm{Mn}$ and $\mathrm{Fe}$ are considered major elements, they are included here as well for comparison with the trace elements (see Appendix Table A2 available at http:// www.terrapub.co.jp/journals/GJ/archives.html).

\section{Comparison of trace element distribution in $T R$ and $I R$}

Compared to the IR from the underlying dolomite, the TR matrix is enriched in $\mathrm{Li}, \mathrm{Be}, \mathrm{Sc}, \mathrm{Mn}, \mathrm{Co}, \mathrm{Ni}, \mathrm{Zn}, \mathrm{Rb}$, $\mathrm{Cd}, \mathrm{Cs}, \mathrm{Tl}$ and $\mathrm{Th}$ (Fig. 2); in contrast, B, V, Cr, Fe, Cu, $\mathrm{Ga}, \mathrm{As}, \mathrm{Pb}, \mathrm{Bi}$ and $\mathrm{U}$ are depleted. The concentrations of $\mathrm{Ti}, \mathrm{Zr}, \mathrm{Nb}$, Hf and Ta in the IR are similar to that deeper in the profile, but are less than in the upper profile. Additionally, Sr, Sn and Ba have similar distributions in both the IR and the TR matrix. Marques et al. (2004) reported that, for trace elements over long periods of pedogenic weathering at acid $\mathrm{pH}$, mono- and divalent cations were leached and depleted, while tri-, tetra- and pentavalent elements accumulated. In the present study, it is not clear that the depletion and enrichment of the trace elements in the TR depended on their valence during weathering. The present results support the previous conclusions of Feng (2011).

Distribution of trace elements in TR and FMCs with depth

In the TR matrix, the concentrations of $\mathrm{Be}, \mathrm{B}, \mathrm{V}, \mathrm{Fe}$, $\mathrm{Cu}, \mathrm{Zn}, \mathrm{Ga}, \mathrm{As}, \mathrm{Cd}, \mathrm{Tl}, \mathrm{Pb}$ and $\mathrm{U}$ tend to increase with depth (Fig. 2). Such a pattern indicates that these elements are removed from the upper and middle sections of the TR profile, transferred downwards, then precipitated at the deepest part of the profile. The concentrations of the high field strength (HFS) elements $\mathrm{Ti}, \mathrm{Zr}, \mathrm{Nb}, \mathrm{Hf}$ and $\mathrm{Ta}$ tend to decrease with depth from 0 to $2.3 \mathrm{~m}$; in contrast, their concentrations exhibit little variation in the deepest part of the profile (2.3-5.4 m). HSF elements are commonly conservative; therefore, their variation in the pro- file indicates that the profile itself is heterogeneous, and also shows the imprint of detritic minerals in the parent rocks. In fact, these results accord with field observations and our previous findings based on quartz features in TR (Feng et al., 2009a).

The concentrations of $\mathrm{Li}, \mathrm{Sc}, \mathrm{Ni}, \mathrm{Rb}$ and $\mathrm{Cs}$ in the TR matrix show an increasing trend in the upper-to-middle depth range, but a decreasing tendency in the deepest part of the profile. Several trace elements, including $\mathrm{Sr}, \mathrm{Ba}$, $\mathrm{Bi}$ and $\mathrm{Th}$, show little variation in the profile; $\mathrm{Sn}$ also exhibits little variation except for two strong peaks within the profile. The concentrations of $\mathrm{Cr}$ and $\mathrm{Mn}$ fluctuate with no clear tendency across the profile, whereas Co concentration tends to decrease with depth.

Generally, the trace element concentrations in FMCs showed complex fluctuating variation with depth (Fig. 2 ). The concentrations of $\mathrm{Be}, \mathrm{Ni}, \mathrm{Cu}, \mathrm{Zn}, \mathrm{As}$ and $\mathrm{Bi}$ fluctuate, but tend to increase with depth; the others fluctuate with no clearly discernable trend. These fluctuating distributions of trace elements with depth in FMCs are similar to those reported by Feng (2011) for another TR profile.

Moreover, Feng (2011) found that Be exhibited a similar geochemical behavior as that of rare earth elements (REEs; except for $\mathrm{Ce}$ ) and $\mathrm{Y}$ in FMCs and TR matrix for another TR profile. Feng (2011) explained that Be may be mobilized and transferred as soluble Be-organic complexes similarly to REEs, and their mobility is highly dependent on $\mathrm{pH}$. In the present work, Be also demonstrated a strong geochemical relationship with REEs (except for $\mathrm{Ce}$ ) in the FMCs and the TR matrix (e.g., $r_{\mathrm{Be}-\mathrm{La}}=$ $0.83, r_{\mathrm{Be}-\mathrm{Lu}}=0.97, P<0.001$ in TR; $r_{\mathrm{Be}-\mathrm{La}}=0.90, r_{\mathrm{Be}-\mathrm{Lu}}$ $=0.91, P<0.001$ in FMCs. see Feng et al., 2011 for REE data); but $\mathrm{Y}$ only in the TR exhibited significant correlation with $\mathrm{Be}\left(r_{\mathrm{Be}-\mathrm{Y}}=0.92, P<0.001\right.$ in $\mathrm{TR} ; r_{\mathrm{Be}-\mathrm{Y}}=0.44$, $P=0.1$ in FMCs). Therefore, a similar geochemical behavior between Be and REEs (except for $\mathrm{Ce}$ ) seems to be a general phenomenon during karst weathering and TR formation.

\section{Enrichment of trace elements in FMCs}

To understand trace element enrichment in FMCs with respect to the surrounding TR matrix, the element enrichment factor $(E F)$ for the FMCs was determined from the relationship suggested by Rankin and Childs (1976):

$$
E F=\frac{\text { element concentration in FMC }}{\text { element concentration in surrounding TR matrix }}
$$

The results are represented in Fig. 3.

Compared to the TR matrix, FMCs were enriched with $\mathrm{Cr}, \mathrm{Mn}, \mathrm{Fe}, \mathrm{Co}, \mathrm{As}, \mathrm{Cd}, \mathrm{Tl}$ and $\mathrm{Pb}$. In contrast, $\mathrm{Li}, \mathrm{Ti}, \mathrm{Ga}$, $\mathrm{Rb}, \mathrm{Sr}, \mathrm{Zr}, \mathrm{Nb}, \mathrm{Sn}, \mathrm{Cs}, \mathrm{Hf}$, Ta and Th show little deple- 


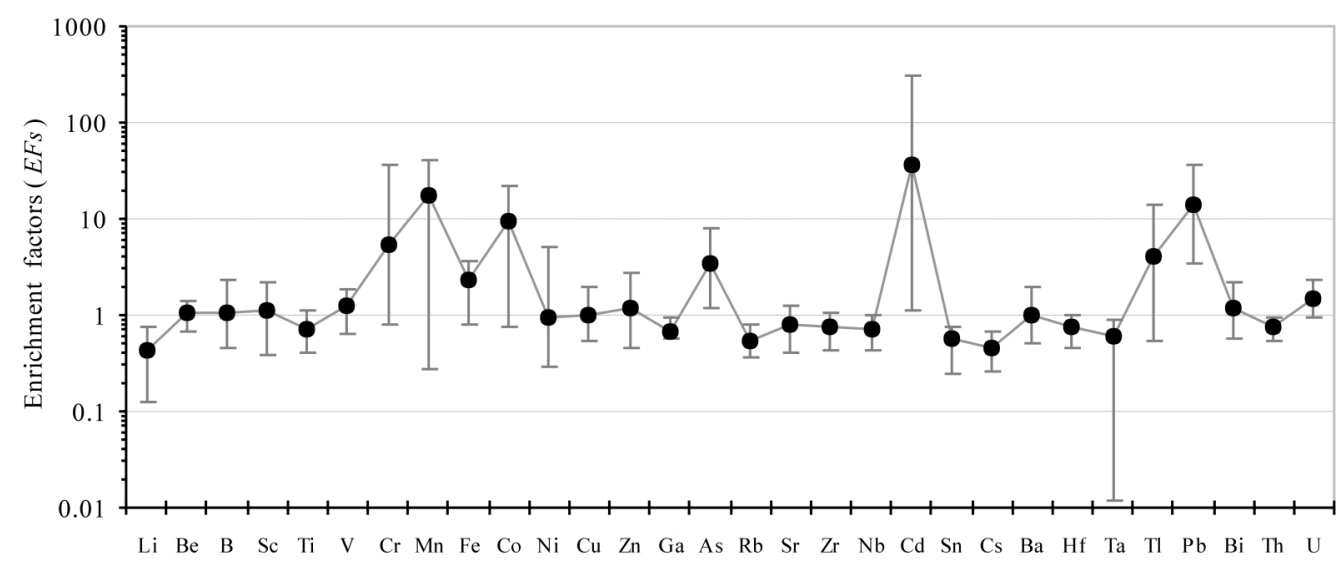

Fig. 3. Distribution pattern of element enrichment factors $(E F=$ element concentration in FMCs/element concentration in surrounding TR matrix) for FMCs. Vertical bars represent the spread of data (min and max).

tion in the FMCs relative to the TR matrix. The $E F$ s for $\mathrm{Be}, \mathrm{B}, \mathrm{Sc}, \mathrm{V}, \mathrm{Ni}, \mathrm{Cu}, \mathrm{Zn}, \mathrm{Ba}, \mathrm{Bi}$ and $\mathrm{U}$ all approach 1 , indicating no discernible enrichment or depletion compared to the matrix. Additionally, none of the trace element $E F$ values fluctuate across the profile with any clear tendency.

During weathering front downward-etching of the local base level, the specific pedoenvironment-such as existing redox condition (Eh and $\mathrm{pH}$ ), reactivity and degree of crystallinity of the $\mathrm{Mn}-\mathrm{Fe}$ phases, together with their relative abundance with depth in the TR profile- - has varied due to tectonic activity and/or climate change (Chao and Theobald, 1976; Bellanca et al., 1996). This change in specific pedoenvironment may directly influence the distribution of trace elements in FMCs with depth.

Trace element partitioning with $M n-F e$ phases in FMCs

In the Dashandong terra rossa profile, it is worth noting that the toxic elements $\mathrm{Cr}, \mathrm{As}, \mathrm{Cd}, \mathrm{Tl}$ and $\mathrm{Pb}$, as well as Co, were significantly enriched in the FMCs compared to the surrounding TR matrix (Fig. 3). Cobalt shows a strong affinity for the Mn phase in the FMCs $\left(r_{\mathrm{Mn}-\mathrm{Co}}=\right.$ $\left.0.80, P<0.001 ; r_{\mathrm{Fe}-\mathrm{Co}}=-0.65, P<0.01\right)$. Associations between toxic elements and $\mathrm{Mn}-\mathrm{Fe}$ phases in the FMCs are set out below.

Chromium $\mathrm{Cr}$ is frequently co-associated with $\mathrm{Fe}$ in natural lateritic Fe-oxide crusts and ferromanganese nodules (Singh and Gilkes, 1992; Schwertmann and Pfab, 1994; Liu et al., 2002; Marques et al., 2004). The data in the present work indicates that the close co-associations of $\mathrm{Cr}$ with $\mathrm{Mn}$ and $\mathrm{Fe}$ are not specific to the formation of FMCs $\left(r_{\mathrm{Mn}-\mathrm{Cr}}=-0.04, P=0.89 ; r_{\mathrm{Fe}-\mathrm{Cr}}=0.01 ; P=0.975\right)$. This is consistent with other results from Fe-oxide crusts (ferricretes) in laterite reported by Marques et al. (2004). Arsenic The enrichment of As in FMCs has been observed and discussed earlier by Rankin and Childs (1976, 1987). Rankin and Childs (1976) suggested that As was associated with an Fe-phase in FMCs. Compared with the TR matrix, FMCs and IR from the underlying dolomite contained much more As. Arsenic enrichment in IR results from the presence of pyrite, since pyrite is generally arsenic-rich (Price and Pichler, 2006). The FMCs had an As concentration between 65.2 and $781.2 \mathrm{ppm}$ (average $313.4 \mathrm{ppm}, n=15)$. For the Dashandong profile, statistical analysis suggests that this is related to the degree of Fe enrichment rather than Mn enrichment $\left(r_{\mathrm{Mn}-\mathrm{As}}=-0.66\right.$, $\left.P<0.01 ; r_{\mathrm{Fe}-\mathrm{As}}=0.84, P<0.001\right)$.

Cadmium Palumbo et al. (2001) reported that $\mathrm{Cd}$ was related to $\mathrm{Mn}$ rather than $\mathrm{Fe}$ enrichment in the ferromanganese nodules of TR. Liu et al. (2002) also observed this behavior in ferromanganese nodules from a Chinese alfisol. In the investigated TR profile, $\mathrm{Cd}$ does not exhibit significant correlation with either $\mathrm{Mn}$ or $\mathrm{Fe}$ in the FMCs $\left(r_{\mathrm{Mn}-\mathrm{Cd}}=0.19, P=0.50 ; r_{\mathrm{Fe}-\mathrm{Cd}}=0.23, P=\right.$ 0.42).

Thallium Bidoglio et al. (1993) and Koschinsky and Halbach (1995) suggested that surface precipitation of $\mathrm{Tl}_{2} \mathrm{O}_{3}$ on $\delta$ - $\mathrm{MnO}_{2}$ as a result of $\mathrm{Tl}(\mathrm{I})$ sorption, and that oxidation at the mineral surface could explain the strong Tl enrichment in the ferromanganese crusts. In the Dashandong profile, Tl has a significant affinity for the Mn-phase in FMCs $\left(r_{\mathrm{Mn}-\mathrm{Tl}}=0.74, P<0.001 ; r_{\mathrm{Fe}-\mathrm{Tl}}=\right.$ $-0.35, P=0.21)$.

Lead Childs (1975) and Rankin and Childs (1987) pointed to higher concentrations of $\mathrm{Pb}$ in FMCs than in the corresponding surrounding soil materials. Cornu et al. (2005) found that accumulation of $\mathrm{Pb}$ in the ferromanganese nodules was due to the high specific adsorption of $\mathrm{Pb}$ by the Mn oxides. In contrast, Palumbo et al. (2001) reported that $\mathrm{Pb}$ appeared to be associated with the Fe-rich phase 


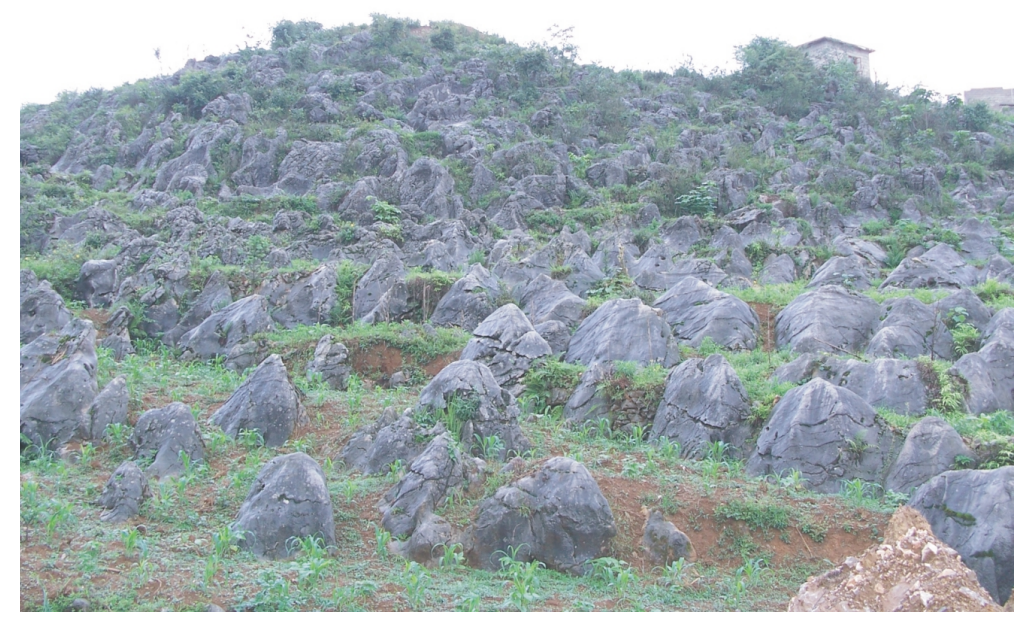

Fig. 4. TR erosion and stone tooth outcropping in karst region on the Yunnan-Guizhou Plateau.

in ferromanganese nodules. The data in the present work indicates that $\mathrm{Pb}$ exhibits a significant affinity for the $\mathrm{Mn}$ phase in FMCs $\left(r_{\mathrm{Mn}-\mathrm{Pb}}=0.79, P<0.001 ; r_{\mathrm{Fe}-\mathrm{Pb}}=-0.36\right.$, $P=0.18)$.

In summary, the present work shows that, in the FMCs, arsenic exhibits significant affinity for $\mathrm{Fe}$; $\mathrm{Cr}$ and $\mathrm{Cd}$ have no significant correlation with either $\mathrm{Mn}$ or $\mathrm{Fe}$; and $\mathrm{Co}$, $\mathrm{Tl}$ and $\mathrm{Pb}$ are related to $\mathrm{Mn}$ rather than $\mathrm{Fe}$.

Feng (2011) reported that FMCs in the Pingba Farm TR profile were significantly enriched in $\mathrm{Mn}, \mathrm{Co}, \mathrm{Cd}, \mathrm{Tl}$ and $\mathrm{Pb}$ compared to the TR matrix. Correspondingly, the $\mathrm{Fe}$ in FMCs did not show discernible enrichment or depletion. Moreover, only Co appeared to be associated with Mn-rich phases in FMCs, whereas $\mathrm{Cd}, \mathrm{Tl}$ and $\mathrm{Pb}$ showed significant affinity for Fe-phases in FMCs. Comparing these findings with the present work implies that the enrichment of $\mathrm{Mn}, \mathrm{Co}, \mathrm{Cd}, \mathrm{Tl}$ and $\mathrm{Pb}$ in the FMCs from the TR profile seems to be a common phenomenon. Corresponding to this, the distributions of $\mathrm{Cr}$, As and even $\mathrm{Fe}$ in the FMCs may vary between TR profiles. It is noteworthy that a close relationship between Co and Mn was found in all the FMCs examined in the TR profiles, which suggests a specific scavenging effect of the $\mathrm{Mn}$ for Co (Taylor and McKenzie, 1966). The toxic elements Cd, Tl and $\mathrm{Pb}$, however, showed different associations within the Mn-Fe phases, further suggesting that the scavenging activity of the $\mathrm{Mn}-\mathrm{Fe}$ phases changes under different pedoenvironments, and may be extremely complex. As the trace element distributions in the FMCs vary with depth, the trace element partitioning in the $\mathrm{Mn}-\mathrm{Fe}$ phases is also governed by the specific pedoenvironment of different TR soil profiles (Feng, 2010, 2011).
Potential desorption of trace elements from FMCs

The present research area is located in the central region of a karst area in south-western China where FMCs are widespread in TR soils and are rich in trace elements (Wang et al., 2001; Feng et al., 2003; Su et al., 2008; Feng, 2010, 2011). However, soil erosion has become a serious environmental problem in the region (Fig. 4; Yuan, 1997; Wang et al., 2004; Huang and Cai, 2007). Aside from the risk of surface soil loss, significant soil erosion potentially involves extensive exposure of the terra rossa base, and especially the FMCs contained in it. Unfortunately, the research region also suffers the most pressing acid rain problem in China (Zhao et al., 1988; Larssen and Carmichael, 2000; Larssen et al., 2000; Hao et al., 2001; Meng et al., 2002). Additionally, TR, especially when it is intensively weathered, has a weak buffering capacity for acid rain, to which it is also vulnerable and sensitive (Tao et al., 2002); thus, acid rain can potentially lead from one disaster to another.

The results of the simulated acid rain experiments are shown in Figs. 5 and 6. These indicate that desorption of toxic trace elements (except arsenic) from FMCs is pHdependent; in general, both the released amounts and desorbability of toxic trace elements from FMCs correlate well with increasing acidity of the simulated acid rain. Different desorption properties of the trace elements in the FMCs were also observed: $\mathrm{Co}, \mathrm{Cd}$ and $\mathrm{Tl}$ were more easily desorbed than either $\mathrm{Cr}$ or $\mathrm{Pb}$ (Fig. 6). No arsenic was detected. Such differences in quantity and desorbability are perhaps caused by the different affinities of the bonding sites to the toxic elements.

Experimental results demonstrate that desorption of 


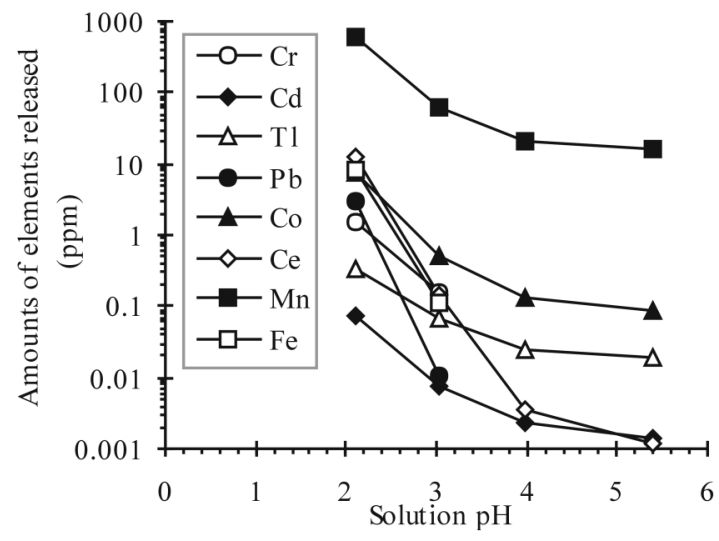

Fig. 5. Amounts of elements released from FMCs treated with simulated acid rain solutions at varied $\mathrm{pH}$.

$\mathrm{Mn}, \mathrm{Fe}$ and $\mathrm{Ce}$ from FMCs is also $\mathrm{pH}$-dependent (Figs. 5 and 6). In contrast to $\mathrm{Fe}, \mathrm{Mn}$ exhibited higher released amounts (Fig. 5), meanwhile $\mathrm{Mn}$ and Ce were more easily desorbed from FMCs (Fig. 6). Feng et al. (2011) reported that the enrichment of Ce in FMCs was correlated with $\mathrm{Mn}$ in the Dashandong TR profile. In addition, a specific scavenging effect of $\mathrm{Mn}$ for Co has been described above. These lines of evidence support that trace elements desorbed from FMCs seem to be mainly derived from those bonded to Mn-phase. As a result, the bioavailability, mobility, and activity of toxic elements in terra rossa soil are all possibly greatly increased by acid rain.

\section{CONCLUSIONS}

Based on our measurements and the discussion above, it was found that:

(1) The concentrations of most trace elements in the terra rossa (TR) in the Dashandong profile did not fall within the range defined by the insoluble residue (IR) from the underlying dolomite. Although it is produced by in situ weathering, the trace element distribution in the TR is not simply inherited from the underlying dolomite. Correspondingly, the characteristics of the trace elements in the TR were significantly overprinted by mobilization, redistribution and fractionation during karst weathering and pedogenesis.

(2) The present work revealed that ferromanganese concretions (FMCs) in the TR matrix contained highly variable trace element compositions at different depths. The concentrations of $\mathrm{Be}, \mathrm{Ni}, \mathrm{Cu}, \mathrm{Zn}, \mathrm{As}$ and $\mathrm{Bi}$ in FMCs fluctuated, tending to increase with depth; the others fluctuated but with no clear trend in the profile. Compared to the TR matrix material, the concretions were found to be

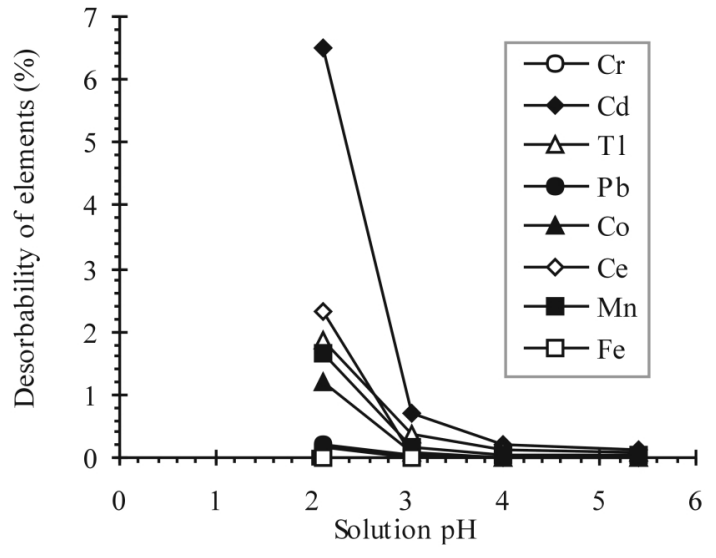

Fig. 6. Desorbability of elements from FMCs as a function of solution $\mathrm{pH}$.

enriched in $\mathrm{Cr}, \mathrm{Mn}, \mathrm{Fe}, \mathrm{Co}, \mathrm{As}, \mathrm{Cd}, \mathrm{Tl}$ and $\mathrm{Pb}$; however, they contained a little less $\mathrm{Li}, \mathrm{Ti}, \mathrm{Ga}, \mathrm{Rb}, \mathrm{Sr}, \mathrm{Zr}, \mathrm{Nb}, \mathrm{Sn}$, Cs, Hf, Ta and Th than the TR matrix, and they showed neither enrichment nor depletion of $\mathrm{Be}, \mathrm{B}, \mathrm{Sc}, \mathrm{V}, \mathrm{Ni}, \mathrm{Cu}$, $\mathrm{Zn}, \mathrm{Ba}, \mathrm{Bi}$ or $\mathrm{U}$. In addition, no clear tendency was observed for the trace element fractionation between FMCs and the corresponding TR matrix. The fluctuation of trace element abundance in FMCs with depth may reflect the specific pedoenvironmental history during FMC formation, with the weathering front etching downwards.

(3) The concentration of the toxic elements $\mathrm{Cr}$, As, $\mathrm{Cd}, \mathrm{Tl}$ and $\mathrm{Pb}$ in the FMCs appeared to be abnormally high. Arsenic typically exhibited a significant affinity for $\mathrm{Fe}$. Neither $\mathrm{Cr}$ nor $\mathrm{Cd}$ showed any significant correlation with either $\mathrm{Mn}$ or $\mathrm{Fe}$, but both $\mathrm{Tl}$ and $\mathrm{Pb}$ showed a preferred association with $\mathrm{Mn}$ rather than Fe. A comparative study revealed that toxic element partitioning in the FMC $\mathrm{Mn}-\mathrm{Fe}$ phases is specific to the pedoenvironment that prevailed during the formation of individual TR soil profiles.

(4) Simulated acid rain experiments indicated that desorption of elements from FMCs is generally $\mathrm{pH}-$ dependent regardless of any other variation in their released quantities and desorbabilities. Moreover, it seems that toxic elements bonded to Mn-phase were easily desorbed from FMCs. As a result, the bioavailability, mobility, and activity of toxic elements from FMCs and TR are potentially increased in field situations where major soil erosion occurs in conjunction with acid rain.

Acknowledgments-We thank Katsuhiko Suzuki, Valter Boero and one anonymous reviewer for their constructive comments. This study was supported by the National Natural Science Foundation of China (NSFC; Grant No. 40471015, 41171008). 


\section{REFERENCES}

Ahmad, S. M. and Husain, A. (1987) Geochemistry of ferromanganese nodules from the Central Indian Basin. Mar. Geol. 77, 165-170.

Bellanca, A., Hauser, S., Neri, R. and Palumbo, B. (1996) Mineralogy and geochemistry of terra rossa soils western Sicily: insights into heavy metal fractionation and mobility. Sci. Total Environ. 193, 57-67.

Bidoglio, G., Gibson, P. N., O’Gorman, M. and Roberts, K. J. (1993) X-ray absorption spectroscopy of surface redox transformations of thallium and chromium on colloidal mineral oxides. Geochim. Cosmochim. Acta 57, 2389-2394.

Burns, R. G. (1976) The uptake of cobalt into ferromanganese nodules soils and synthetic manganese (IV) oxides. Geochim. Cosmochim. Acta 40, 95-102.

Calvert, S. E. and Piper, D. Z. (1984) Geochemistry of ferromanganese nodules from DOMES site A, Northern Equatorial Pacific: Multiple diagenetic metal sources in the deep sea. Geochim. Cosmochim. Acta 48, 1913-1928.

Chao, T. T. and Theobald, P. K., Jr. (1976) The significance of secondary iron and manganese oxides in geochemical exploration. Econ. Geol. 71, 1560-1569.

Childs, C. W. (1975) Composition of iron-manganese concretions from New Zealand soils. Geoderma 13, 141-152.

Cornu, S., Deschatrettes, V., Salvador-Blanes, S., Clozel, B., Hardy, M., Branchut, S. and Forestier, L. L. (2005) Trace element accumulation in $\mathrm{Mn}-\mathrm{Fe}$-oxide nodules of a planosolic horizon. Geoderma 125, 11-24.

Dawson, B. S. W., Fergusson, J. E., Campbell, A. S. and Cutler, E. J. B. (1985) Distribution of elements in some Fe-Mn nodules and an iron-pan in gley soils of New Zealand. Geoderma 35, 127-143.

Durn, G. (2003) Terra rossa in the Mediterranean region: parent materials, composition and origin. Geologia Croatica 56, 83-100.

Durn, G., Ottner, F. and Slovenec, D. (1999) Mineralogical and geochemical indicators of the polygenetic nature of terra rossa in Istria, Croatia. Geoderma 91, 125-150.

Feng, J.-L. (2010) Behavior of rare earth elements and yttrium in ferromanganese concretions, gibbsite spots, and the surrounding terra rossa over dolomite during chemical weathering. Chem. Geol. 271, 112-132.

Feng, J.-L. (2011) Trace elements in ferromanganese concretions, gibbsite spots, and the surrounding terra rossa overlying dolomite: Their mobilization, redistribution and fractionation. J. Geochem. Explor. 108, 99-111.

Feng, J.-L., Cui, Z.-J., Zhang, W., Liu, G.-N. and Zhu, L.-P. (2003) Dating materials of lateritic weathering mantles in Yun-Gui Plateau of China: Basis researches of manganese nodules. Mar. Geol. Quat. Geol. 23, 45-54 (in Chinese with English abstract).

Feng, J.-L., Cui, Z.-J. and Zhu, L.-P. (2009a) Origin of terra rossa over dolomite on the Yunnan-Guizhou Plateau China. Geochem. J. 43, 151-166.

Feng, J.-L., Zhu, L.-P. and Cui, Z.-J. (2009b) Quartz features constrain the origin of terra rossa over dolomite on the Yunnan-Guizhou Plateau. China. J. Asian Earth Sci. 36, 156-167.
Feng, J.-L., Gao, S.-P. and Zhang, J.-F. (2011) Lanthanide tetrad effect in ferromanganese concretions and terra rossa overlying dolomite during surface weathering. Chem. ErdeGeochem. 71, 349-362.

Glasby, G. P., Gwozdz, R., Kunzendorf, H., Friedrich, G. and Thijssen, T. (1987) The distribution of rare earth and minor elements in manganese nodules and sediments from the equatorial and S.W. Pacific. Lithos 20, 97-113.

Hao, J., Duan, L., Zhou, X. and Fu, L. (2001) Application of a LRT Model to acid rain control in China. Environ. Sci. Technol. 35, 3407-3415.

Huang, Q. H. and Cai, Y. L. (2007) Spatial pattern of karst rock desertification in the Middle of Guizhou Province, Southwest China. Environ. Geol. 52, 1325-1330.

Ji, H., Wang, S., Ouyang, Z., Zhang, S., Sun, C., Liu, X. and Zhou, D. (2004) Geochemistry of red residua underlying dolomites in karst terrains of Yunnan-Guizhou Plateau: I. The formation of the Pingba profile. Chem. Geol. 203, 127.

Koschinsky, A. and Halbach, P. (1995) Sequential leaching of marine ferromanganese precipitates: genetic implications. Geochim. Cosmochim. Acta 59, 5113-5132.

Larssen, T. and Carmichael, G. R. (2000) Acid rain and acidification in China: the importance of base cation deposition. Environ. Pollut. 110, 89-102.

Larssen, T., Schnoor, J. L., Seip, H. M. and Zhao, D. (2000) Evaluation of different approaches for modeling effects of acid rain on soils in China. Sci. Total Environ. 246, 175193.

Latrille, C., Elsass, F., van Oort, F. and Denaix, L. (2001) Physical speciation of trace metals in $\mathrm{Fe}-\mathrm{Mn}$ concretions from a rendzic lithosol developed on Sinemurian limestones (France). Geoderma 100, 127-146.

Liu, F., Colombo, C., Adamo, P., He, J. Z. and Violante, A. (2002) Trace elements in manganese-iron nodules from a Chinese Alfisol. Soil Sci. Soc. Am. J. 66, 661-670.

Marques, J. J., Schulze, D. G., Curi, N. and Mertzman, S. A. (2004) Trace element geochemistry in Brazilian Cerrado soils. Geoderma 121, 31-43.

McKenzie, R. M. (1975) An electron microprobe study of the relationships between heavy metals and manganese and iron in soils and ocean floor nodules. Aust. J. Soil Res. 13, 177188.

McKenzie, R. M. (1980) The adsorption of lead and other heavy metals on oxides of manganese and iron. Aust. J. Soil Res. 18, 61-73.

Mee, A. C., Bestland, E. A. and Spooner, N. A. (2004) Age and origin of terra rossa soils in the Coonawarra area of South Australia. Geomorphology 58, 1-25.

Meng, F., Xu, J., He, Y., Cheng, Q., Jing, F. and Tang, X.-Y. (2002) A regional scale analysis and control strategy for $\mathrm{SO}_{2}$ pollution and acid deposition in Guiyang City. Res. Environ. Sci. 15, 24-26.

Merino, E. and Banerjee, A. (2008) Terra rossa genesis, implications for karst, and eolian dust: A geodynamic thread. $J$. Geol. 116, 62-75.

Miko, S., Durn, G. and Prohić, E. (1999) Evaluation of terra rossa geochemical baselines from Croatian karst regions. J. Geochem. Explor. 66, 173-182. 
Muhs, D. R. and Budahn, J. R. (2009) Geochemical evidence for African dust and volcanic ash inputs to terra rossa soils on carbonate reef terraces, northern Jamaica, West Indies. Quatern. Int. 196, 13-35.

Muhs, D. R., Budahn, J., Skipp, G., Prospero, J. M., Patterson, D. and Bettis, E. A., III (2010) Geochemical and mineralogical evidence for Sahara and Sahel dust additions to Quaternary soils on Lanzarote, eastern Canary Islands, Spain. Terra Nova 22, 399-410.

Ostrom, M. E. (1961) Separation of clay minerals from carbonate rocks by using acid. J. Sediment. Res. 31, 123-129.

Palumbo, B., Angelone, M., Bellanca, A., Dazzi, C., Hauser, S., Neri, R. and Wilson, J. (2000) Influence of inheritance and pedogenesis on heavy metal distribution in soils of Sicily Italy. Geoderma 95, 247-266.

Palumbo, B., Bellanca, A., Neri, R. and Roe, M. J. (2001) Trace metal partitioning in $\mathrm{Fe}-\mathrm{Mn}$ nodules from Sicilian soils Italy. Chem. Geol. 173, 257-269.

Price, R. E. and Pichler, T. (2006) Abundance and mineralogical association of arsenic in the Suwannee Limestone (Florida): Implications for arsenic release during water-rock interaction. Chem. Geol. 228, 44-56.

Qi, L., Hu, J. and Gregoire, D. C. (2000) Determination of trace elements in granites by inductively coupled plasma mass spectrometry. Talanta 51, 507-513.

Rabenhorst, M. C. and Wilding, L. P. (1984) Rapid method to obtain carbonate-free residues from limestone and petrocalcic materials. Soil Sci. Soc. Am. J. 48, 216-219.

Rankin, P. C. and Childs, C. W. (1976) Rare-earth elements in iron-manganese concretions from some New Zealand soils. Chem. Geol. 18, 55-64.

Rankin, P. C. and Childs, C. W. (1987) Rare earths and other trace elements in iron-manganese concretions from a catenary sequence of yellow-grey earth soils, New Zealand. N.Z. J. Geol. Geophys. 30, 199-202.

Schwertmann, U. and Pfab, G. (1994) Structural vanadium in synthetic goethite. Geochim. Cosmochim. Acta 58, 43494352.

Singer, A. (2007) The Soils of Israel. Springer, p. 102-106.

Singh, B. and Gilkes, R. J. (1992) Properties and distribution of iron oxides and their associations with minor elements in the soil of south-western Australia. Eur. J. Soil Sci. 43, 77-98.

Su, C.-T., Tang, J.-S., Shan, H.-P., Chen, H.-F., Xia, R.-Y. and
Zou, S.-Z. (2008) Study on the geochemical properties of $\mathrm{Fe}-\mathrm{Mn}$ nodule in Litang karst area. Carsologica Sinica 27, 43-49 (in Chinese with English abstract).

Tao, F., Hayashi, Y. and Lin, E. (2002) Soil vulnerability and sensitivity to acid deposition in China. Water Air Soil Pollut. 140, 247-260.

Taylor, R. M. and McKenzie, R. M. (1966) The association of trace elements with manganese minerals in Australian soils. Aust. J. Soil Res. 4, 29-39.

Taylor, S. R. and McLennan, S. M. (1985) The Continental Crust: Its Composition and Evolution. Blackwell Scientific Publications, London.

Verlaan, P. A., Cronan, D. S. and Morgan, C. L. (2004) A comparative analysis of compositional variations in and between marine ferromanganese nodules and crusts in the South Pacific and their environmental controls. Prog. Oceanogr. 63, 125-158.

Wang, D.-Z., Jiang, X., Rao, W. and He, J.-Z. (2009) Kinetics of soil cadmium desorption under simulated acid rain. Ecol. Complex. 6, 432-437.

Wang, S., Ji, H., Ouyang, Z., Zhou, D., Zheng, L. and Li, T. (1999) Preliminary study on carbonate rock weathering pedogenesis. Sci. in China (D) 42, 572-581.

Wang, S., Liu, Q. and Zhang, D. (2004) Karst rocky desertification in southwestern China: Geomorphology, landuse, impact and rehabilitation. Land Degrad. Dev. 15, 115-121.

Wang, Y.-G., Wang, L.-T. and Cheng, G.-F. (2001) Preliminary study on ferromanganese nodules in the Xinpu district of Guanling, Guizhou. Guizhou Geol. 18, 7-11 (in Chinese with English abstract).

Whitehead, N. E., Hunt, J., Leslie, D. and Rankin, P. (1993) The elemental content of Niue Island soils as an indicator of their origin. N.Z. J. Geol. Geophys. 36, 243-255.

Williams, T. M. and Owen, R. B. (1992) Geochemistry and origins of lacustrine ferromanganese nodules from the Malawi Rift, Central Africa. Geochim. Cosmochim. Acta 56, 27032712.

Yaalon, D. H. (1997) Soils in the Mediterranean region: what makes them different? Catena 28, 157-169.

Yuan, D. (1997) Rock desertification in the subtropical karst of South China. Z. Geomorphol. Suppl. 108, 81-90.

Zhao, D., Xiong, J., Xu, Y. and Chan, W. H. (1988) Acid rain in southwestern China. Atmos. Environ. 22, 349-358. 